Article

\title{
The Relationship between User Perception and Preference of Greenway Trail Characteristics in Urban Areas
}

\author{
Junga Lee ${ }^{1}\left(\mathbb{D}\right.$, Hyung-Sook Lee ${ }^{2} \mathbb{C}$, Daeyoung Jeong ${ }^{3}$, C. Scott Shafer ${ }^{4}$ and Jinhyung Chon ${ }^{3, *}$ \\ 1 Department of Forestry and Landscape Architecture, Sanghuh College of Life Sciences, \\ Konkuk University, 120 Neungdong-ro, Gwangjin-gu, Seoul 05029, Korea \\ 2 Department of Landscape Architecture, Kyungpook National University, 80 Daehakro, Bukgu, \\ Daegu 41566, Korea \\ 3 Division of Environmental Science \& Ecological Engineering, College of Life Sciences and Biotechnology, \\ Korea University, 145 Anam-ro, Seongbuk-gu, Seoul 02841, Korea \\ 4 Recreation, Park and Tourism Sciences, Texas A\&M University, College Station, TX 77840, USA \\ * Correspondence: jchon@korea.ac.kr; Tel.: +82-02-3290-3048
}

Received: 15 June 2019; Accepted: 12 August 2019; Published: 16 August 2019

\begin{abstract}
Greenways provide multiple benefits for trail users' individual experiences based on users' background environment and their perceptions of characteristics such as the trail width, vegetation, water, and facilities. Although greenway trail characteristics are important factors that affect users' preferences, only a few studies have examined individuals' experiences of greenways based on their perceptions and preferences. The purpose of this study is to examine how greenway trails can be designed to improve users' experiences in relation to their perceptions and preferences by considering trail characteristics. We examine the relationship between greenway trail characteristics and likability using $t$-tests as well as correlation and multiple regression analyses. In the current study, virtual tour surveys of greenway users were conducted, with two urban greenway trails as the study sites: Town Lake Trail in Austin, Texas, and Buffalo Bayou Trail in Houston, Texas. Perceptions of all eight greenway trail characteristics, except for background buildings, were significantly different between the trails, and a significant difference in likability was found for five characteristics (the presence of water, trail facilities, trail width, adjacent automobile traffic, and built structures on the trail). In addition, the results of the correlation and multiple regression analyses revealed that the presence of water, amount of vegetation, automobile traffic, and built structures were correlated with likability. These findings suggest that designing appropriate types of greenway trails can help increase users' likeability ratings of urban greenways. This study contributes to the enhancement of trail environments by providing strategies for practitioners to effectively design and manage greenways.
\end{abstract}

Keywords: greenway; trail characteristics; user perceptions; user preferences; likability; greenway planning and design

\section{Introduction}

Green infrastructure has been used to address issues such as environmental degradation and problems in urban communities. Greenways are primary resources that promote the important role of green infrastructure and provide multiple benefits to local communities by enhancing community vitality and ecological sustainability [1-4]. The term "greenway" refers to a linear corridor that plays a role in connecting open spaces such as linking parks, natural reserves, cultural features, or historic sites with each other and with populated areas or natural corridors [5]. Greenways are created from ecologically important natural corridors, and in urban areas, multifunctional corridors have 
been developed as green infrastructure. Greenways are also intended to ecologically reconnect the fragmented landscape because habitat fragmentation is considered a serious threat to biodiversity. For example, Burley [6] focused on the restoration and management of migratory bird habitats through a greenway network and presented a wide range of landscape planning and management measures. In addition, greenways have not only captured attention due to connecting urban ecosystems [7] but, from a social perspective, are also recognized as places for recreation and as areas that maintain the scenic quality of the landscapes in urban areas [8]. In other words, greenways provide benefits to individuals in the form of scenic views and access to a variety of experiences related to health, recreation, alternative transportation, and tourism at the community level (e.g., [3,5,8-14]). Many studies have examined human interactions with the natural environment, especially greenways, due to the benefits that such interactions offer [15-18], and thus, "an affective state is an important indicator of the nature and significance of a person's ongoing interaction with an environment" [19]. Research has also found that aesthetic factors have major influences on judgments of community satisfaction [20] and that aesthetic variables are rated highest among various variables regarding the quality of residential environment [21,22]. Therefore, in advancing the understanding of human interaction with greenways, both planners and designers must understand greenway users' experiences to effectively design and manage greenways in urban areas [23]. However, few studies have addressed individuals' experiences with trail-based greenways or how these experiences may relate to design features such as trail characteristics $[13,24,25]$. Trail characteristics are related to physical attributes such as width, trail surface, amount of vegetation, presence of water, trail facilities, background buildings, built structures on the trail, and automobile traffic [25-27]. In many studies, these physical trail characteristics have been considered highly relevant to design objectives, such as linking diverse user experiences, and aesthetic responses to landscape resources have been most frequently examined [28-33]. This study focuses on the interaction between humans and the environment from a visual perspective that includes individuals' perceptions and preferences. This study also considers the relationship between physical trail characteristics and individuals' perceptions and preferences to improve the physical conditions of greenways in urban areas in terms of planning, design, and management.

\subsection{Research Background of the Study}

Trail characteristics are different types of physical attributes of urban greenways associated with trail experiences [25-27]. Gobster [25] found several trail attributes that influenced the trail experience, including the smoothness (or roughness) of the trail tread, the proximity of the trail to automobile traffic, and the visibility of water and trees. Trail attributes include tread width, tread surface material, thickness of vegetation, trailside support facilities (e.g., benches), background buildings (e.g., skyline), and structures constructed along the trail (e.g., a bridge overpass). In addition to the length and connection of the trail, other factors are important in the development of a successful greenway network [25,34,35]. The tread surface is considered an important attribute in the use of trails [26]; tread surface refers to the part of the trail that is most proximate to the user, and it is an important factor in trail use. The tread can be constructed from a variety of materials, ranging from natural soil to crushed stone, asphalt, concrete, recycled plastic, and/or wood. Without regard to construction costs and maintenance, each material affords a somewhat different experience for trail users. The desire for a particular surface material and the width of the trail tread are often dependent upon the type and amount of use [36]. In Gobster's study [25], a well-maintained tread surface was mentioned more than any other positive attribute by trail users, while a rough trail surface was the most frequently mentioned characteristic that users disliked on trails.

The perception of a trail tread as too narrow may be related to the density and type of trail use, such as high-activity use (e.g., fast walking, running, calisthenics, roller-skating, skateboarding, roller skiing, and skiing), medium-activity use (e.g., walking, slow walking, and bicycling), and low-activity use (e.g., standing, sitting, riding in a stroller, picnicking, and laying down) [37]. 
People tend to choose relatively attractive spaces. Good landscapes are related to the pleasure that people experience in a place, the memory of a place, and the elements that a place represents $[12,13,38,39]$. The attractiveness of the trail is related to the trail infrastructure, e.g., restroom facilities fountains, shelters, signage, etc., constructed in the proximity of the trail [40]. These facilities can positively impact user preference by enhancing the visual and physical experience for the user [41]. In addition, urban landscapes are known to increase the visibility of the natural landscape, such as plants, mountains, and rivers, as well as that of the artificial landscape, which can have a negative effect on preferences [24,42]. Accordingly, people's visual preferences can be used to measure their attitudes regarding a particular place [42].

To better understand the aesthetic elements in landscape design, construction, and management, preference assessments that measure users' opinions should be conducted [43]. There are various ways to assess the landscape. For example, direct landscape evaluation is often the result of the interactions between the visual characteristics of the observation target and the observer's experiences and knowledge. Using this approach, assessments of greenway preferences have addressed the relationship between individual likability and different types of landscapes [13,44-47]. In other words, likability is reflected in the level of people's perceptions of the attractiveness of each part of the landscape. Likeability is conveyed through users' feelings, and the likability of a greenway trail influences the potential use of the trail due to individual responses to its aesthetic properties. Despite the increasing interest in greenways, there is a lack of research on users' preferences in open spaces, including greenways. To date, research on preferences has not examined the relationship between perceptions of the natural environment and aesthetic responses. As observed in many studies, preference measurements and community responses play an important role in creating an objective basis for decision making and policy development [12,13,39,42]. Recently, urban greenways have been discussed in relation to the trail characteristics associated with user experiences [24,25,48,49]. Trail characteristics are important factors in greenway design that affect users' preferences, and specific trail characteristics should align with users' preferences. Nonetheless, many planners and designers offer design guidelines from an engineering perspective rather than from the perspective of users' experiences [23]. Although many previous studies on greenways have provided basic guidelines for greenway design [50-53], only a few studies have considered the trail characteristics associated with greenway use patterns [24]. Therefore, it is necessary to provide information on the design, layout, and maintenance of greenway trail corridors based on aesthetic research on environmental awareness. This approach will improve our understanding of how urban greenways are perceived by users and can be useful for the design and development of greenways.

\subsection{Study Objectives}

The purpose of this study was to demonstrate a better understanding of how a greenway trail can be laid out and designed to enhance users' experiences. To explore these experiences, we focused on users' perceptions and preferences, which can be examined through the likability of a greenway trail. This study had two primary objectives. First, we examined whether and how perceptions and likability might differ if characteristics along a greenway trail corridor scene were changed. Second, we analyzed whether users' perceptions of trail characteristics affect the overall likability of the greenway. The results of this analysis can improve our understanding of the trail characteristics that may be influenced by greenway planning and design.

\subsection{Hypotheses}

Hypothesis 1. There are significant differences between respondents' perceptions of existing trail characteristics and altered greenway trail characteristics.

Hypothesis 2. There are significant differences between the likability of existing and altered greenway trail characteristics. 
Hypothesis 3. There is a significant correlation between respondents' perceptions and likability of greenway trail characteristics.

Hypothesis 4. There are significant positive relationships between respondents' perceptions of trail characteristics and the overall likability of a trail.

\section{Materials and Methods}

\subsection{Study Area}

The study areas were two urban greenways, namely, Town Lake Trail (Trail A) and Buffalo Bayou Trail (Trail B), which are located in two cities (Austin and Houston, TX, USA, respectively) (Figure 1). Both trails are located in central urban areas with frequent views of background skylines, foreground buildings, roadways, bridges, and water features. (Figures 2 and 3). The trails are good places for hiking and cycling because they are mostly flat and there are excellent scenic views of the city. The trails also vary in their tread width and surface material and have different amounts of adjacent vegetation and trailside facilities. Thus, these greenways were selected as study sites because they have high user frequency and varied trail characteristics [24].

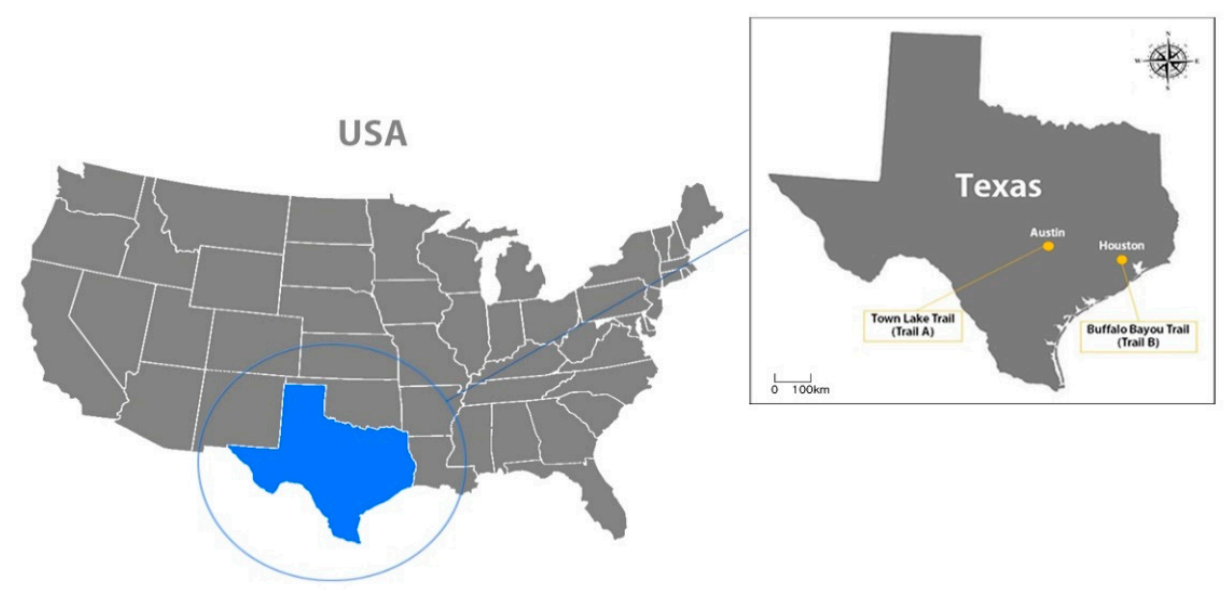

Figure 1. Key map showing the studied trails.

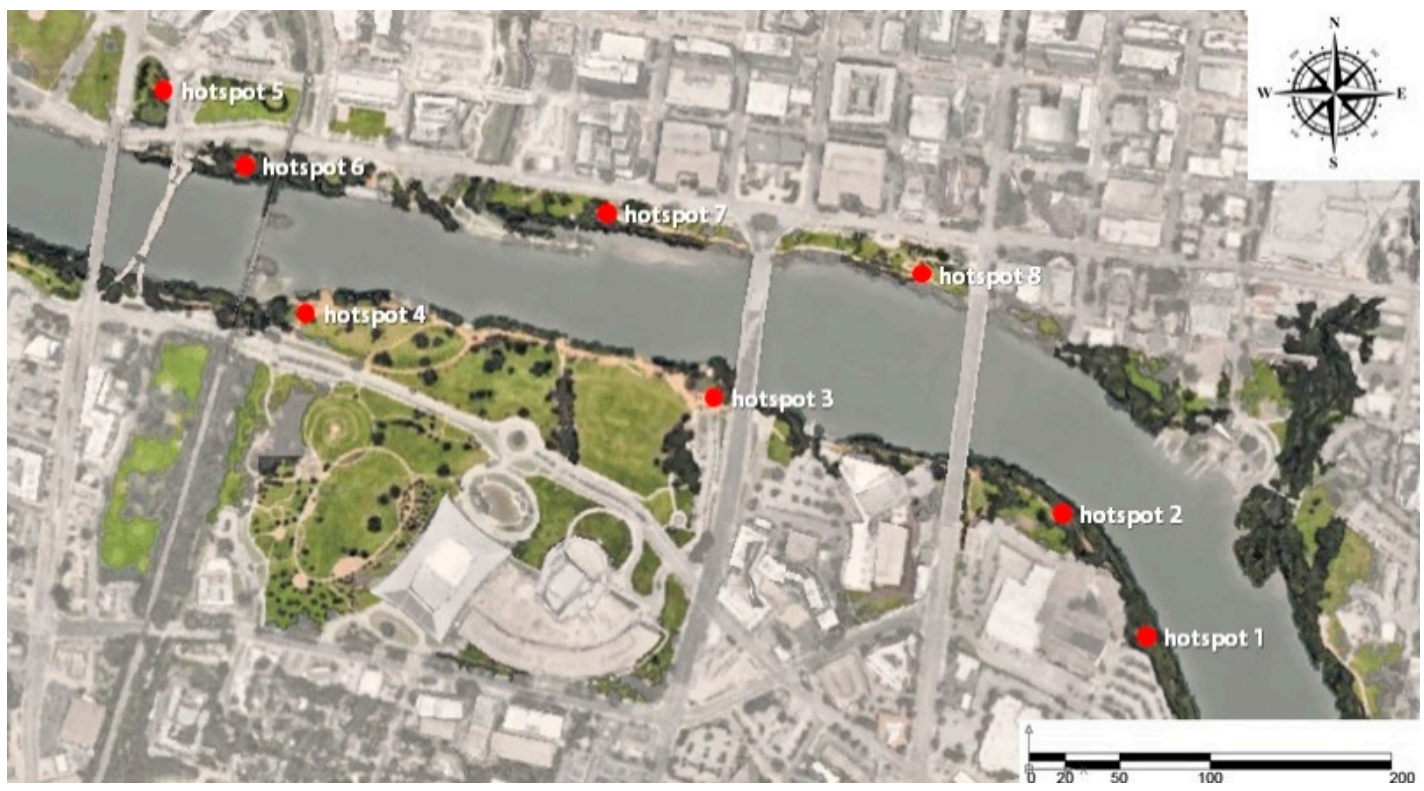

Figure 2. Locations of the virtual assessments of Town Lake Trail (Trail A). 


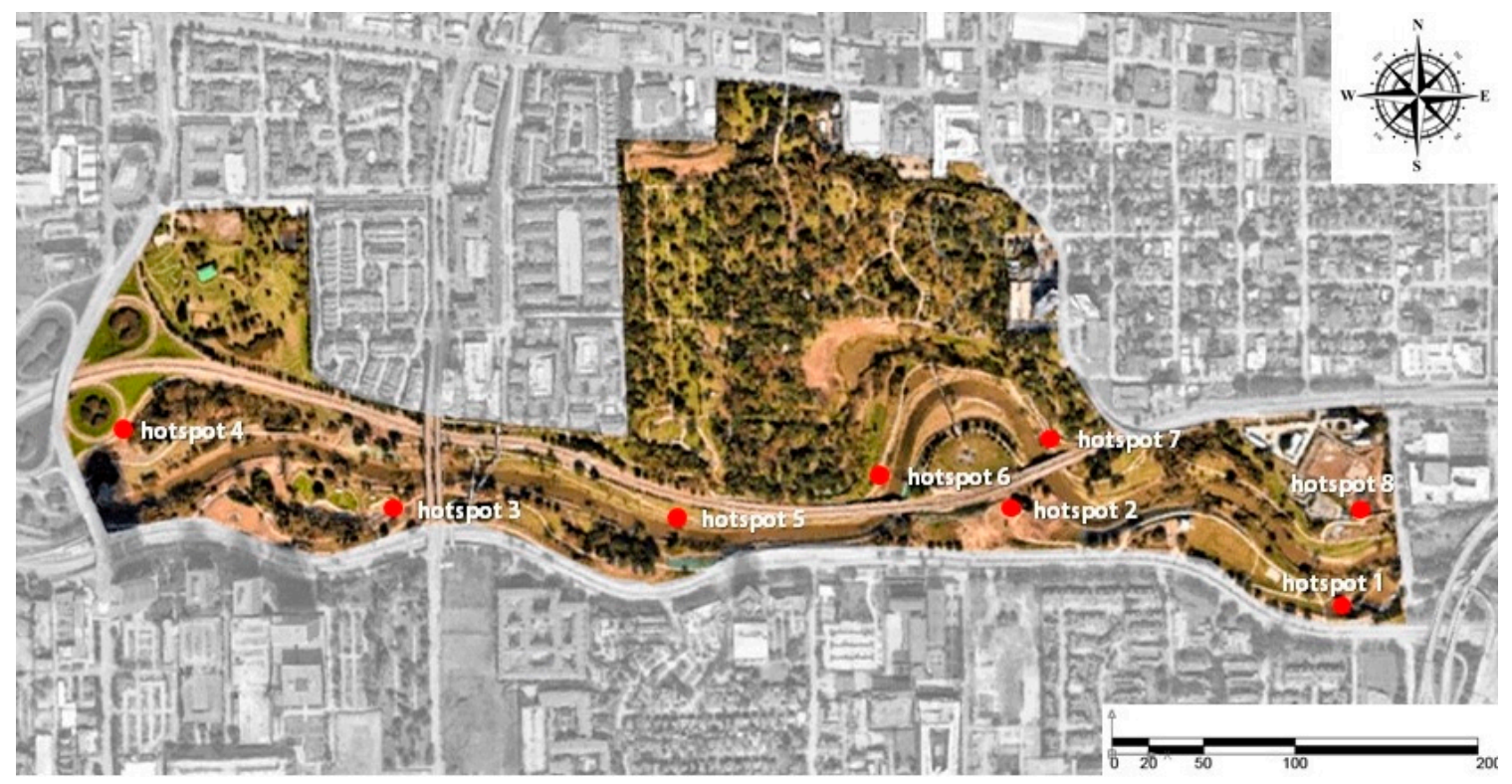

Figure 3. Locations of the virtual assessments of Buffalo Bayou Trail (Trail B).

\subsection{Experimental Design}

This study used a quasi-experimental design to examine how trails are perceived when certain independent variables are manipulated. We conducted a web-based virtual tour to understand how the trails were perceived by users when the visual environment variables of the study sites were manipulated. Mahdjoubi and Wiltshire [54] suggest that environmental simulation techniques such as web-based virtual tours are crucial for communication and input during the environmental design decision-making process. The virtual experience can reveal how potential visitors would evaluate the appearance of urban greenway trails by asking respondents to evaluate particular elements [55]. In addition, web-based virtual tours are a type of laboratory-based experimental study, which can overcome several difficulties, such as economic issues and insufficient control in the real environment [56-58]. Figure 4 illustrates the conceptual model used in the study, and Figures 5-8 provide examples of the actual scenes and the related altered scenes.

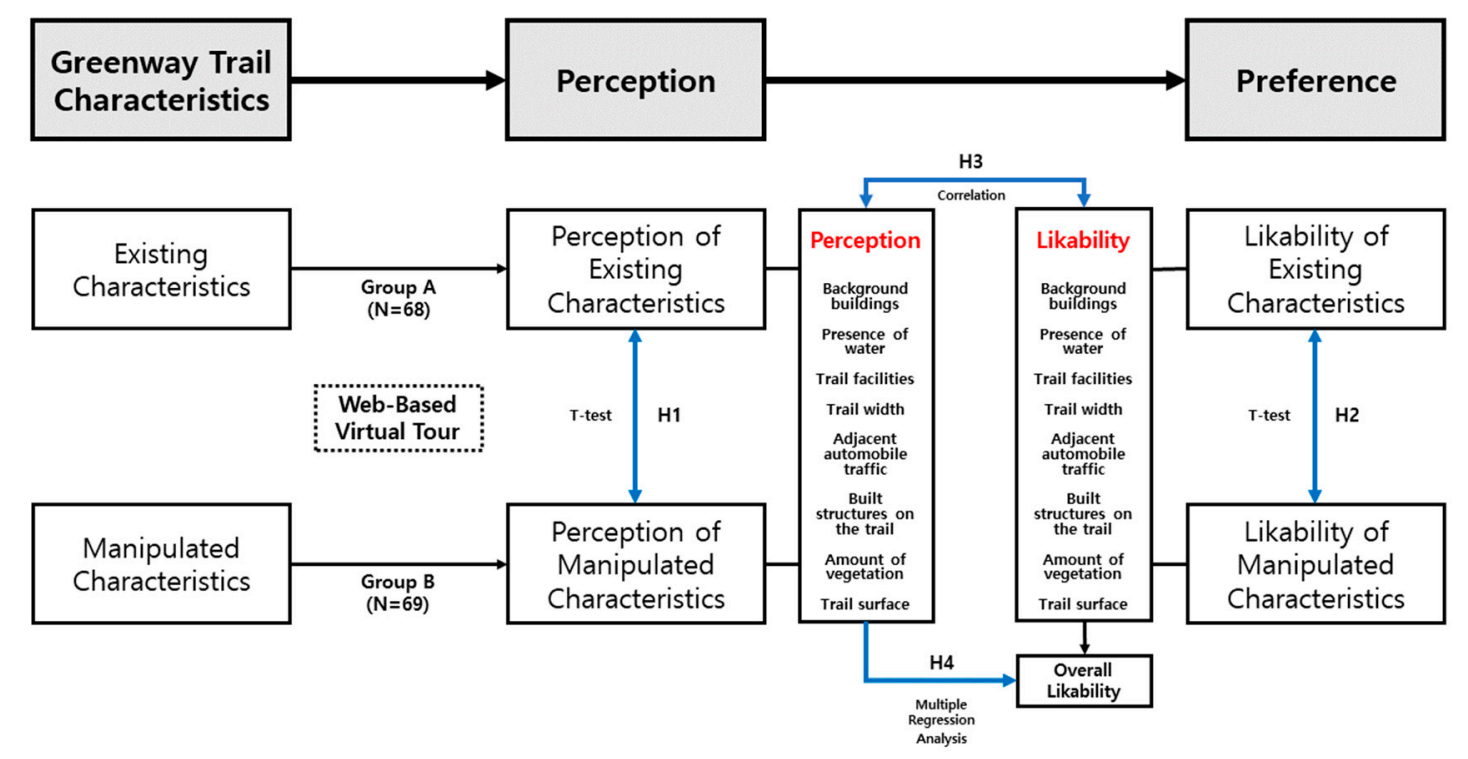

Figure 4. Conceptual model of the study. 


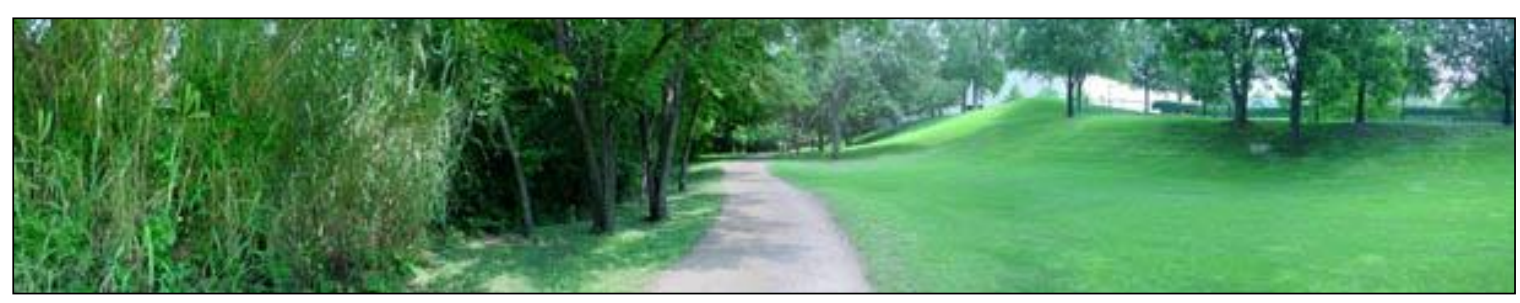

Figure 5. Example of a viewpoint of Trail A with the existing view.

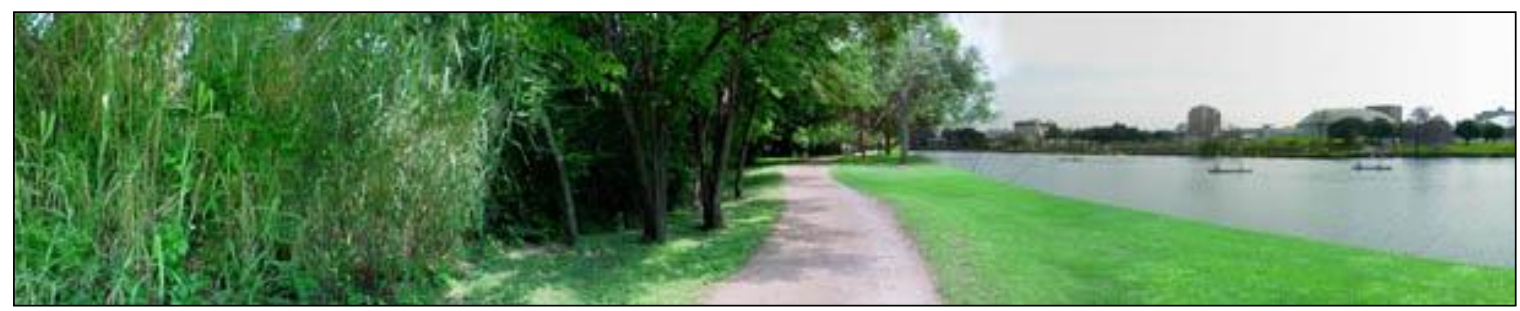

Figure 6. Example of a viewpoint of Trail A with a manipulated view, i.e., addition of a body of water.

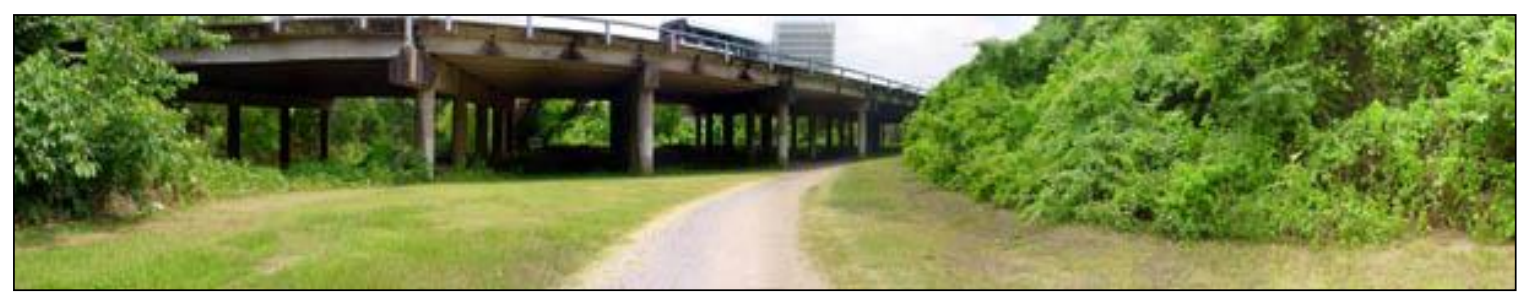

Figure 7. Example of a viewpoint of Trail B with the existing view.

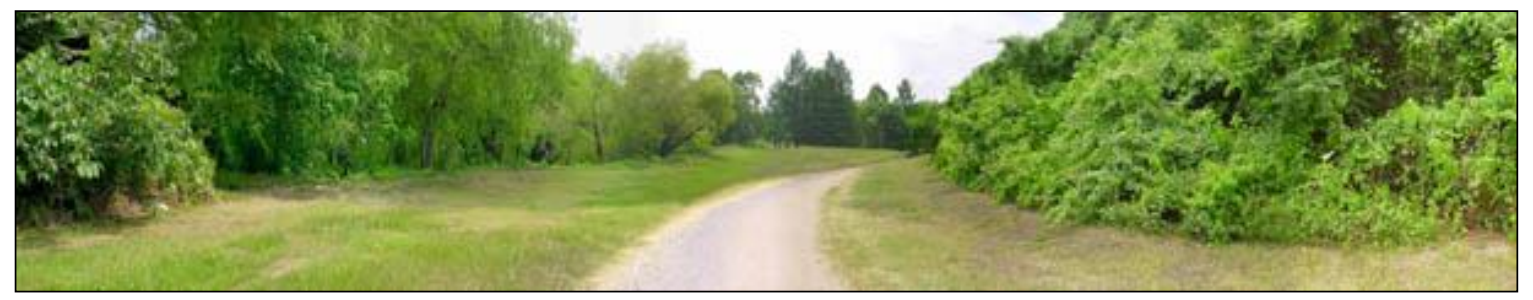

Figure 8. Example of a viewpoint of Trail B with a manipulated view-overpass bridge removed.

First, a treatment of the trail characteristics was created for each site. Trail characteristics including the trail width, trail surface, amount of vegetation, presence of water, trailside facilities, background skylines, foreground structures such as bridges, trailside structures such as benches, and automobile traffic were evaluated in each scene. The treatments were developed to alter characteristics such as the trail tread surface (e.g., harder vs. softer) and width (e.g., narrower vs. wider); presence or absence of trail-specific facilities (e.g., benches, water fountains); presence or absence of background skylines; presence or absence of adjacent automobile traffic; amount and location of vegetation; and presence of built structures, such as bridges or utility infrastructure, in the foreground adjacent to the trail. Eight points on each trail were selected through discussion with landscape architects, which were considered for each characteristic to represent the specific characteristics of broad attributes.

Second, the virtual tour processes were conducted differently for the two groups. Two different groups of subjects each viewed a series of eight (8) scenes from Trail A or Trail B. Group A experienced a trail environment with the current conditions of the trail characteristics, and Group B experienced the characteristics of the greenway trail in a modified environment.

Third, differences in perception and likability of trail characteristics between the groups were analyzed using a $t$-test, and the correlation between the likability of trail characteristics was assessed. In addition, multiple regression analyses were performed to verify the relationship between respondents' 
perceptions of trail characteristic and the degree to which they preferred these characteristics. All statistical analyses were performed using IBM SPSS 24.0 program (SPSS Inc., Chicago, IL, USA).

\subsection{Measures}

The measures used for this study can be categorized into four main sections: demographic characteristics, past trail activity experience, perceptions of trail characteristics, and likability. First, the questions about past trail activity experience were structured as follows: "How often (never; once a year; few times a year; monthly; weekly; or daily) do you engage in each activity (walking; running; bicycling; in-line skating; and motorcycling)?" Second, the questions about the respondents' perceptions of the trail characteristics were rated on a 5-point Likert scale; the respondents were asked to evaluate how they perceived the trail characteristics in each scene, from "too little or not enough" to "too much". For trail width, the scale ranged from "too narrow" to "too wide"; for trail surface, the scale ranged from "too soft" to "too hard"; and for vegetation and water, the scale ranged from "not enough" to "too much". On each scale, the midpoint was "about right". Third, to measure the likeability of the greenway trail characteristics, the questions asked about the overall experience of the trail based on a series of 8 scenes along the trail corridor. The questions were also rated on a 5-point Likert scale from "not at all" to "very much"; the questions included, "How much do you like this trail segment based on all the spots you viewed along it?" and "How much would you like to visit this trail?" The final measure collected demographic information.

\subsection{Data Collection and Analysis}

A total of 137 questionnaires were collected (Table 1). The participants, who were graduate and undergraduate students at Texas A\&M University, were randomly assigned to one of the two experimental groups (Group A =68, Group B =69). The demographic characteristics of the respondents are shown in Table 1 . This study sample was not representative of any particular population given that previous experimental studies have used homogeneous groups as samples $[59,60]$. The perceptions of past trail activity experience of Groups A and B are also shown in Table 1.

Table 1. Demographic characteristics.

\begin{tabular}{cccc}
\hline & & Group A $(\boldsymbol{n = 6 8 )}$ & Group B $(\boldsymbol{n}=\mathbf{6 9})$ \\
\hline Age & Mean & $23.1(4.79)$ & $22.0(2.69)$ \\
\hline \multirow{2}{*}{ Gender } & Male $(\%)$ & $33(48.5 \%)$ & $37(53.6 \%)$ \\
& Female & $35(51.5 \%)$ & $32(46.4 \%)$ \\
\hline \multirow{2}{*}{ Past Trail Activity Experience } & Walking & 4.51 & 4.71 \\
(Mean) & Running & 3.77 & 4.20 \\
& Bicycling & 3.07 & 3.09 \\
& In-line skating & 1.43 & 1.46 \\
& Motorcycling & 1.81 & 1.97 \\
\hline
\end{tabular}

The visual images and related questions were administered in a designated computer room with consistent machine types and monitor sizes to help control the level of image quality and to standardize the experience as much as possible across subjects. This process was intentionally performed in a computer room under the supervision of the researcher to provide an opportunity for individual respondents to see the images clearly and to control for the possibility of changes in spatial and temporal conditions among different locations. Each group visited the designated computer room, sat in front of the monitor and completed the experiments. Before the experiments, the researcher told the respondents that they would be interacting with a virtual greenway. The respondents were able to move at their own pace through a series of 8 scenes along the trail corridor. After the opportunity to view the scene, the respondents were prompted to answer a series of questions about the scene. Group A viewed scenes that depicted the trail and related corridor as it currently existed. Group 
B viewed the same scenes with characteristics added or removed to (1) assess how the participants perceived the presence or absence of a characteristic in a scene and (2) test the potential influence of each characteristic on how subjects rated the "likeability" of that portion of the trail corridor.

To analyze whether and how the participants' perceptions and the degree of likability differed based on changes to the greenway trail corridor scenes, independent-sample $t$-tests were performed. We also analyzed the correlations to examine the relationship between trail experiences and preferences in greenway trails and between perceptions of trail characteristics and overall likability. Additionally, multiple regressions were performed to find the strongest predictors of likability.

\section{Results}

\subsection{Perception of Greenway Trail Characteristics}

Group A, who viewed the existing trail images, perceived that the trail width, traffic, and amount of vegetation looked "about right", as the mean values of those items were 2.51, 2.91, and 2.43, respectively. The Group A participants perceived that there were too many built structures (3.37) and that the trail surface looked too hard (3.35); they also perceived a lack of bodies of water (1.51) and trail facilities (1.69) in the pictures (Figure 9).

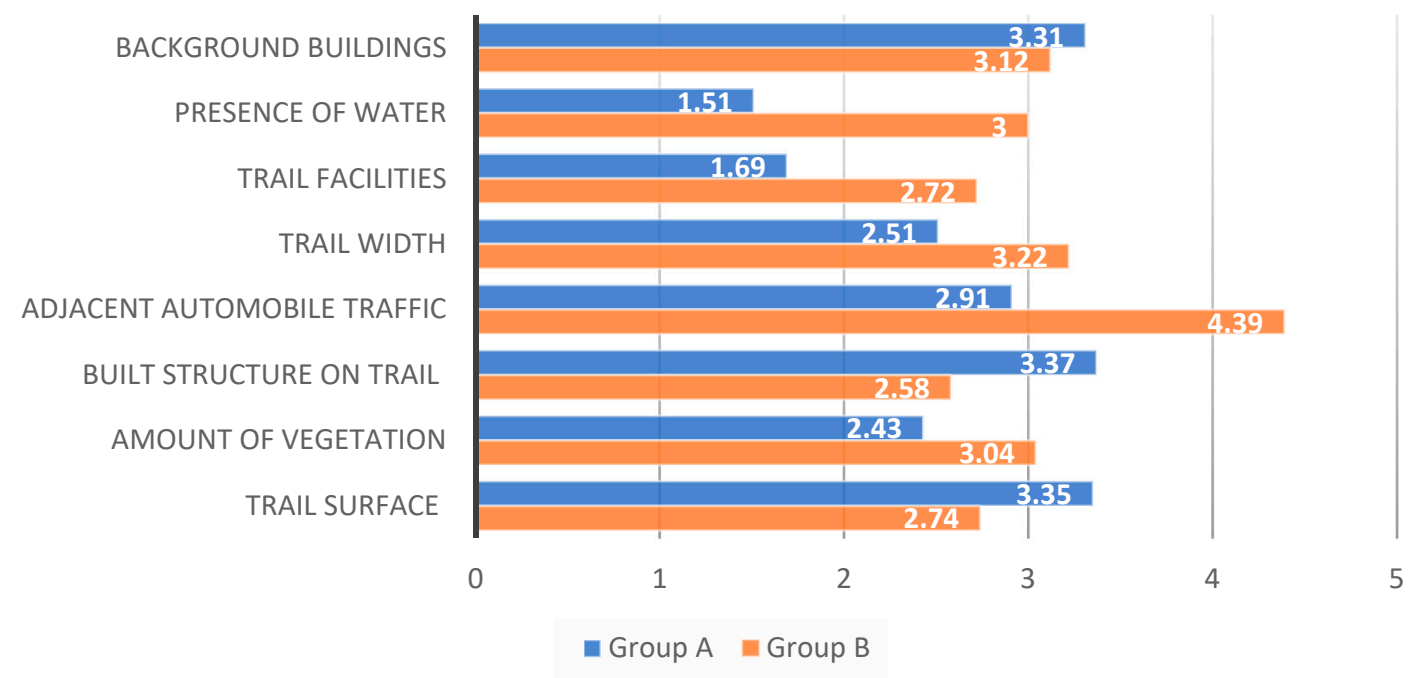

Figure 9. Comparison of the perceptions of trail characteristics.

For Group B, who viewed the manipulated images in which the building backgrounds had been removed, bodies of water had been added, trail facilities had been added, built structures had been removed, vegetation had been added, and softer surfaces had been added, perceived the trail characteristics as "about right", ranging from 2.72 to 4.39 .

\subsection{Differences in the Perceptions of the Existing and Manipulated Characteristics}

We compared the overall mean scores between Group A and Group B using independent-sample $t$-tests to verify whether the participants' perceptions differed depending on the manipulation of the greenway trail characteristics. The results showed a significant difference in all variables except for background buildings (Table 2). Therefore, Hypothesis 1 (there are significant differences between respondents' perceptions of existing trail characteristics and altered greenway trail characteristics) was partially confirmed.

Although the image with the background buildings removed was perceived as "about right" (3.12) compared to the existing image (3.31), the difference was not significant. The most significant difference in perception was found between the image with the traffic removed (2.91) and the existing trail with a view of buildings (4.39). Additionally, adding water features or trail facilities made respondents feel 
that the characteristics were "enough" or "about right". The existing trail width and vegetation were perceived as sufficient, and the widened trail and added vegetation were perceived as "too much".

Table 2. Differences in perceptions between the groups that viewed the existing and manipulated characteristics.

\begin{tabular}{|c|c|c|c|c|c|}
\hline $\begin{array}{c}\text { Greenway Trail Characteristics } \\
\text { Treatment }\end{array}$ & Group & Mean & SD & $t$-Value & $p$-Value \\
\hline \multirow{2}{*}{$\begin{array}{l}\text { Background buildings } \\
\text { (Buildings removed) }\end{array}$} & Group A & 3.31 & 0.74 & \multirow{2}{*}{1.39} & \multirow{2}{*}{0.168} \\
\hline & Group B & 3.12 & 0.88 & & \\
\hline \multirow{2}{*}{$\begin{array}{l}\text { Presence of water } \\
\text { (Water added) }\end{array}$} & Group A & 1.51 & 0.76 & \multirow{2}{*}{-11.82} & \multirow{2}{*}{$0.000\left(^{*}\right)$} \\
\hline & Group B & 3.00 & 0.71 & & \\
\hline \multirow{2}{*}{$\begin{array}{c}\text { Trail facilities } \\
\text { (Facilities added) }\end{array}$} & Group A & 1.69 & 0.78 & \multirow{2}{*}{-5.77} & \multirow{2}{*}{$0.000\left(^{*}\right)$} \\
\hline & Group B & 2.72 & 1.26 & & \\
\hline \multirow{2}{*}{$\begin{array}{c}\text { Trail width } \\
\text { (Trail tread widened) }\end{array}$} & Group A & 2.51 & 0.94 & \multirow{2}{*}{-5.19} & \multirow{2}{*}{$0.000\left(^{*}\right)$} \\
\hline & Group B & 3.22 & 0.62 & & \\
\hline \multirow{2}{*}{$\begin{array}{l}\text { Adjacent automobile traffic } \\
\text { (Automobile traffic added) }\end{array}$} & Group A & 2.91 & 0.54 & \multirow{2}{*}{-10.98} & \multirow{2}{*}{$0.000\left(^{*}\right)$} \\
\hline & Group B & 4.39 & 0.97 & & \\
\hline \multirow{2}{*}{$\begin{array}{l}\text { Built structures on the trail } \\
\text { (Structures removed) }\end{array}$} & Group A & 3.37 & 1.17 & \multirow{2}{*}{4.65} & \multirow{2}{*}{$0.000\left(^{*}\right)$} \\
\hline & Group B & 2.58 & 0.77 & & \\
\hline \multirow{2}{*}{$\begin{array}{l}\text { Amount of vegetation } \\
\text { (Vegetation added) }\end{array}$} & Group A & 2.43 & 0.85 & \multirow{2}{*}{-3.24} & \multirow{2}{*}{$0.001\left(^{*}\right)$} \\
\hline & Group B & 3.04 & 1.32 & & \\
\hline \multirow{2}{*}{$\begin{array}{c}\text { Trail surface } \\
\text { (Surface softened) }\end{array}$} & Group A & 3.35 & 0.93 & \multirow{2}{*}{3.68} & \multirow{2}{*}{$0.000\left(^{*}\right)$} \\
\hline & Group B & 2.74 & 1.02 & & \\
\hline
\end{tabular}

Note: Group A ( $n=68)$ : group who viewed the existing trail characteristics; Group B $(n=69)$ : group who viewed the manipulated trail characteristics, ${ }^{*} p \leq 0.001$, two-tailed.

\subsection{Differences in Likability between the Existing and Manipulated Characteristics}

The likability of each trail characteristic within the existing environment and the altered environment showed significant differences, as shown in Table 3. The results showed that the presence of water $(p \leq 0.001)$, trail width $(p \leq 0.001)$, adjacent automobile traffic $(p \leq 0.001)$, built structures on the trail $(p \leq 0.001)$, and trail facilities $(p \leq 0.05)$ were significantly different in terms of likability between the existing and manipulated images. The mean likability values of the images with the manipulated characteristics were lower than those of the images with the nonmanipulated characteristics. However, the respondents' likability ratings of the images in the background buildings, amount of vegetation, and trail surface treatments showed no significant differences between the existing and manipulated images, although the respondents' perceptions of these trail characteristics differed significantly. Therefore, Hypothesis 2 (there are significant differences between the likability of the existing and altered greenway trail characteristics for respondents) was partially confirmed. 
Table 3. Differences in likability values between the groups who viewed the existing and manipulated characteristics.

\begin{tabular}{|c|c|c|c|c|c|}
\hline $\begin{array}{c}\text { Greenway Trail Characteristics } \\
\text { Treatment }\end{array}$ & Group & Mean & SD & $t$-Value & $p$-Value \\
\hline \multirow{2}{*}{$\begin{array}{l}\text { Background buildings } \\
\text { (Buildings removed) }\end{array}$} & Group A & 3.1 & 0.81 & \multirow[b]{2}{*}{-0.91} & \multirow{2}{*}{0.365} \\
\hline & Group B & 3.25 & 1.02 & & \\
\hline \multirow{2}{*}{$\begin{array}{l}\text { Presence of water } \\
\text { (Water added) }\end{array}$} & Group A & 3.51 & 0.95 & \multirow{2}{*}{-4.59} & \multirow{2}{*}{$0.000{ }^{(* * *)}$} \\
\hline & Group B & 4.19 & 0.75 & & \\
\hline \multirow{2}{*}{$\begin{array}{c}\text { Trail facilities } \\
\text { (Facilities added) }\end{array}$} & Group A & 3.04 & 1.13 & \multirow{2}{*}{-2.39} & \multirow[b]{2}{*}{$0.018\left(^{*}\right)$} \\
\hline & Group B & 3.46 & 0.92 & & \\
\hline \multirow{2}{*}{$\begin{array}{c}\text { Trail width } \\
\text { (Trail tread widened) }\end{array}$} & Group A & 3.26 & 0.97 & \multirow{2}{*}{3.27} & \multirow{2}{*}{$0.001{ }^{(* * *)}$} \\
\hline & Group B & 2.7 & 1.06 & & \\
\hline \multirow{2}{*}{$\begin{array}{l}\text { Adjacent automobile traffic } \\
\text { (Automobile traffic added) }\end{array}$} & Group A & 3.5 & 1.23 & \multirow{2}{*}{4.64} & \multirow{2}{*}{$0.000\left(^{* * *}\right)$} \\
\hline & Group B & 2.58 & 1.09 & & \\
\hline \multirow{2}{*}{$\begin{array}{l}\text { Built structures on the trail } \\
\text { (Structures removed) }\end{array}$} & Group A & 2.91 & 1.43 & \multirow{2}{*}{-4.47} & \multirow{2}{*}{$0.000\left(^{* * *}\right)$} \\
\hline & Group B & 3.86 & 1 & & \\
\hline \multirow{2}{*}{$\begin{array}{l}\text { Amount of vegetation } \\
\text { (Vegetation added) }\end{array}$} & Group A & 3.6 & 1.26 & \multirow{2}{*}{-0.64} & \multirow{2}{*}{0.525} \\
\hline & Group B & 3.74 & 1.24 & & \\
\hline \multirow{2}{*}{$\begin{array}{l}\text { Trail surface } \\
\text { (Surface softened) }\end{array}$} & Group A & 3.43 & 1.1 & \multirow{2}{*}{-0.04} & \multirow{2}{*}{0.965} \\
\hline & Group B & 3.43 & 1.14 & & \\
\hline
\end{tabular}

Note: Group A ( $n=68)$ : group who viewed the existing trail characteristics; Group B $(n=69)$ : group who viewed the manipulated trail characteristics, ${ }^{*} p \leq 0.05,{ }^{* *} p \leq 0.01,{ }^{* * *} p \leq 0.001$, two-tailed.

\subsection{Correlations between Perception and Likability of the Greenway Trails Characteristics}

To examine the relationship between trail experiences and preferences for greenway trails, we analyzed the correlation between perceptions and likability of greenway trail characteristics. Hypothesis 3 was tested using Pearson's correlation analysis. The results showed that the presence of water, amount of vegetation, automobile traffic, and built structures were correlated with likability, with correlation coefficients of 0.262-0.454 (Table 4). More water features, less automobile traffic, and fewer built structures on the trail were related to high likability. However, vegetation was negatively related to likability. Therefore, Hypothesis 3 (there is a significant correlation between respondents' perceptions of trail characteristics and overall likability) was partially confirmed.

Table 4. Correlation coefficients among perception and likability of the greenway trail characteristics for all groups.

\begin{tabular}{cc}
\hline Variables & Correlation Coefficient \\
\hline Background buildings & 0.048 \\
Presence of water & $0.262\left(^{* *}\right)$ \\
Trail facilities & 0.100 \\
Trail width & -0.084 \\
Adjacent automobile traffic & $-0.351\left(^{* *}\right)$ \\
Built structures on the trail & $-0.285\left(^{* *}\right)$ \\
Amount of vegetation & $-0.454\left(^{* *}\right)$ \\
Trail surface & -0.010 \\
\hline Note: ${ }^{*} p \leq 0.05,{ }^{* *} p \leq 0.01,{ }^{* * *} p \leq 0.001$, two-tailed.
\end{tabular}

Multiple regression analysis was performed to determine which variables were the strongest predictors of likability. Since the regression model with overall likability as the dependent variable was not significant $\left(R^{2}=0.045, p>0.05\right)$, we used an item that asked respondents, "How inviting is this portion of the trail?", as the dependent variable. Because this study used a virtual tour, this question was judged to be a good surrogate for likability. That is, the respondents were not truly in the place 
but rather were reacting to how they would feel if they were there and whether the landscape was a place they would like to be.

The results of the multiple regression analysis showed that several greenway trail characteristics were related to likability (Table 5). Six of the eight greenway trail characteristics, namely, trail width, trail surface, amount of vegetation, background buildings, built structures, and adjacent automobile traffic on the trail, were significant at the 0.05 level. That is, six of the eight characteristics measured had predictive value in relation to how inviting the virtual trail was to the viewer. Therefore, Hypothesis 4 (There are significant positive relationships between respondents' perceptions of trail characteristics and the overall likability of a trail.) was partially confirmed.

Table 5. Multiple regression analysis of greenway trail characteristics on likability for all groups.

\begin{tabular}{cccccc}
\hline \multirow{2}{*}{ Variables } & \multicolumn{2}{c}{$\begin{array}{c}\text { Unstandardized } \\
\text { Coefficients }\end{array}$} & $\begin{array}{c}\text { Standardized } \\
\text { Coefficients }\end{array}$ & \multirow{2}{*}{$\boldsymbol{t}$-Value } & $\boldsymbol{p}$-Value \\
\cline { 2 - 4 } & $\mathbf{B}$ & SE & Beta & & \\
\hline Constant & 1.226 & 0.144 & & 8.517 & 0.000 \\
Background buildings & 0.131 & 0.044 & 0.091 & 3.006 & $0.003\left(^{*}\right)$ \\
Presence of water & 0.034 & 0.033 & 0.025 & 1.043 & 0.297 \\
Trail facilities & 0.070 & 0.036 & 0.048 & 1.927 & 0.054 \\
Trail width & 0.068 & 0.035 & 0.047 & 1.961 & $0.049\left(^{*}\right)$ \\
Adjacent automobile traffic & 0.126 & 0.038 & 0.089 & 3.339 & $0.001\left(^{*}\right)$ \\
Built structures on the trail & 0.170 & 0.044 & 0.119 & 3.877 & $0.000\left(^{*}\right)$ \\
Amount of vegetation & 0.218 & 0.038 & 0.146 & 5.809 & $0.000\left(^{*}\right)$ \\
Trail surface & 0.105 & 0.040 & 0.063 & 2.652 & $0.008\left(^{*}\right)$ \\
\hline
\end{tabular}

Note: ${ }^{*} p<0.05$ was considered to indicate significance. The dependent variable is inviting $\mathrm{R}^{2}=0.146, \mathrm{Adj}$. $\mathrm{R} 2=$ $0.142, \mathrm{~F}=35.767, p=0.000$.

\section{Discussion}

According to the results of users' perceptions and likability ratings, this study shows how greenway characteristics affect users' experiences in relation to their perceptions and preferences and how people respond to the prominent features of greenways.

The main finding in this study is that users' preferences for greenway characteristics are related to cognitive factors. This is because visual preferences, according to the stimuli-response process, are a response to physical stimuli. In this study, a statistically significant factor was derived by analyzing differences in perceptions and preferences between different groups with regard to greenway characteristics. In other words, before investigating visual preferences for greenway characteristics, the extent to which greenway characteristics are recognized must be determined.

In the analysis of the manipulated versus nonmanipulated trail characteristics on the greenway trails, there were significant differences in the perceptions of seven trail characteristics (the presence of water, trail facilities, trail width, adjacent automobile traffic, built structures on the trail, amount of vegetation, and trail surface). On the other hand, there were significant differences in users' likability ratings for only five trail characteristics (the presence of water, trail facilities, trail width, adjacent automobile traffic, and built structures on the trail). The results of this study show that changes to those five trail characteristics can significantly improve respondents' evaluations of trail likability as well as their perceptions of these characteristics. In other words, the addition of or changes to certain elements of greenway trails, such as added water or widened trails, could help make greenways become more likable. The results of this study are consistent with previous studies and support research trends. In particular, Gobster [25] identified scenic beauty, nearby water, trees, and rolling hills as positive attributes for trail users. These results imply that four trail characteristics, including the presence of water, trail facilities, trail width, and built structures on trails, are more important than other characteristics for users' perceptions and evaluations of likability. However, some of the results are different from those of Gobster [25], who found that trail width and surface are important factors 
related to trail use. Gobster emphasized the importance of the trail width and surface as factors that provide users with a variety of ecological experiences; however, in this study, no significant difference was found between the perceptions of the different trail widths or preferences for changes in the surface. That is, the trail width and surface may be a sensitive issue for users who experience a trail directly, but these factors do not affect users' visual preferences.

From the multiple regression analysis, we found that greenway trail characteristics including trail width, trail surface, amount of vegetation, background buildings, built structures, and adjacent automobile traffic on trails were significant predictors of likability. Previous studies have consistently shown that natural elements such as vegetation have a positive interaction with the greenway trail environment [14-16,30]. This study also provided evidence to support that vegetation was significant in relation to likability, as shown in the literature. In addition, the findings of this study confirmed that the trail width, trail surface, background buildings, built structures, and adjacent automobile traffic on the trails had a significant relationship with likability. However, there was no significant relationship between the presence of water or trail facilities and likability. This finding indicates that a managed and unique landscape can also improve people's aesthetic experiences in greenway corridors through built structures such as bridges, utility plants, and other human structures. Although trail facilities and the presence of water were not significant predictors of likability on greenway trails, the results indicated that people perceived a more inviting environment on greenways with water or more trail facilities. This finding suggests that the presence of trail facilities and water may make greenways feel more comfortable and are preferred by users.

Therefore, with regard to these characteristics, the likeability of a greenway can be modified by changing the existing environment. Many recent attempts have been made to integrate the socioeconomic factors or land use patterns in the community into the design of the greenway. Doing so requires users to create an environment that encourages people to have increased experiences with the trail landscape [61]. For example, if a trail is connected to tourism attractions, such as an historic landmark or local events, the user's quality of experience increases. In other words, greenway design is not just about changing the physical environment, but it must also incorporate the development of vantage points to improve views, while connecting various land uses. Given that the design of the trail potentially affects the level of use, policymakers and trail managers must establish a plan that incorporates vegetation management and link the various land use possibilities.

\section{Conclusions}

Urban greenways provide social, ecological, psychological, and sociocultural benefits to society that enhance urban dwellers' well-being and quality of life, factors that promote sustainable communities. The majority of early studies regarding greenways and trails are mainly concerned with the major functions of these environmental assets, such as their ecological significance, their historic and cultural value, and the recreational opportunities they offer. Less attention has been given to user perception and its relationship to the characteristics of the greenways and trails. One of the major objectives of this study was to identify a way (design cue) to improve the physical conditions of greenway trails, their characteristics, and their corridors in urban areas to better serve the multiple objectives of greenways for sustainable communities. Nassauer [62] suggests that design cues reveal powerful messages of ecological beauty that reflect human care and stewardship. For example, with respect to greenway trails, these design cues may include vegetation to screen unattractive nuisance elements.

Several managerial implications of greenway trail design, including trail characteristics, are suggested based on the results of this study. For example, the amount of vegetation along the trail influences user likability of the greenway. This study's findings further confirmed that a high level of preference was given to environments with large amounts of vegetation $[45,47]$ and that natural beauty is a primary reason why people visit greenway trails [25]. Trail facilities such as lighting, benches, shelters, and trash containers are also significant factors that influence users' perceptions of trails [25]. Therefore, practitioners should consider how to locate and manage vegetation and trail facilities from 
a perspective of both aesthetics and safety. In addition, results indicate that background buildings, built structures, and adjacent auto traffic are significantly correlated with user likability and preference likability. Tourists and residents often commented that a combination of well-managed natural and built environments is attractive in urban areas and that they enhance the image of the city [38]. This implies that planners and designers should consider how to minimize visual conflicts or maximize visual access with certain associated elements when designing trails.

To understand the needs and preferences of the user, it is necessary to promote public involvement in the planning and design process. The benefits of public involvement in planning and design, which have been widely documented [55,63], include strengthening people's sense of commitment to the place, increasing user satisfaction, and creating realistic expectations of outcomes [64]. Public participation in planning and design can be augmented through the use of visualization techniques for better communication [63]. Future studies should explore diverse hands-on methods of participation techniques to provide a clearer descriptive understanding of user preference.

There are certain limitations to this study. Since the sample was homogeneous, the generalizability of the research results is limited. Future studies, therefore, must incorporate a more representative sample of the general population. Furthermore, investigating likability within different groups and subcultures will enhance and maintain the quality of the environment and thereby induce sustainable development. In addition, because there may be substantial variances in trail characteristics due to location and culture [23], future studies must identify and explore the factors that influence users' preferences in various contexts.

Evidently, greenways provide numerous benefits both for people and for the environment in a multitude of ways [7]. This study has confirmed that the benefits of greenways are often related to greenway characteristics that contribute to expanded views and enhance the perceived experiences of the people. In cities and urban areas, greenways often offer attractions, activities, and increased local opportunities by providing aesthetic transitions from levees to neighborhoods, preserving and protecting aesthetic resources, and managing unique human infrastructure.

Author Contributions: J.C. and C.S.S. conceived and design the study questions, methodology, and collected data; J.L. and J.C. developed the study and interpreted the findings and wrote the paper. H.-S.L. participated in data analysis and helped improve the discussion. D.J. helped conduct the literature review and data analysis. All the authors have read and approved the final manuscript.

Funding: The research was supported by the Department of Recreation, Park and Tourism Sciences, Texas A\&M University, USA. This paper was supported by the KU Research Professor Program of Konkuk University by the development of new research ideas. This work was also supported by the National Research Foundation of Korea (NRF) grant funded by Korea government (MEST) (No. 2017R1A2B4008866).

Conflicts of Interest: The authors declare no conflict of interest.

\section{References}

1. Benedict, M.; McMahon, E. Green Infrastructure: Smart Conservation for the 21st Century; Sprawl Watch Clearinghouse Monograph Series. 2002. Available online: http://www.sprawlwatch.org/greeninfrastructure. pdf (accessed on 15 June 2019).

2. Larson, L.R.; Keith, S.J.; Fernandez, M.; Hallo, J.C.; Shafer, C.S.; Jennings, V. Ecosystem services and urban greenways: What's the public's perspective? Ecosyst. Serv. 2016, 22, 111-116. [CrossRef]

3. Weber, S.; Boley, B.B.; Palardy, N.; Gaither, C.J. The impact of urban greenways on residential concerns: Findings from the Atlanta BeltLine Trail. Landsc. Urban Plan. 2017, 167, 147-156. [CrossRef]

4. Fan, S.; Chen, X.; Ren, H.; Shen, W.; Xiao, R.; Zhang, Q.; Wu, Z.; Su, Y. Landscape structure and network characteristics of the greenway system in Guangzhou City, South China. Landsc. Ecol. Eng. 2019, 15, 25-35. [CrossRef]

5. Little, C.E. Greenways for America; JHU Press: Baltimore, MD, USA, 1995.

6. Burley, J.B. International greenways: A Red River Valley case study. Landsc. Urban Plan. 1995, 33, $195-210$. [CrossRef] 
7. Searns, R.M. The evolution of greenways as an adaptive urban landscape form. Landsc. Urban Plan. 1995, 33, 65-80. [CrossRef]

8. Moore, R.L.; Shafer, C.S. Introduction to special issue trails and greenways: Opportunities for planners, managers, and scholars. J. Park Recreat. Adm. 2001, 19, 1-16.

9. Hay, K.G. Greenways and biodiversity. In Landscape Linkages and Biodiversity; Island Press: Washington, DC, USA, 1991; pp. 162-175.

10. Kent, R.L.; Elliott, C.L. Scenic routes linking and protecting natural and cultural landscape features: A greenway skeleton. Landsc. Urban Plan. 1995, 33, 341-355. [CrossRef]

11. Lynn, N.A.; Brown, R.D. Effects of recreational use impacts on hiking experiences in natural areas. Landsc. Urban Plan. 2003, 64, 77-87. [CrossRef]

12. Shafer, C.S.; Lee, B.K.; Turner, S. A tale of three greenway trails: User perceptions related to quality of life. Landsc. Urban Plan. 2000, 49, 163-178. [CrossRef]

13. Keith, S.J.; Larson, L.R.; Shafer, C.S.; Hallo, J.C.; Fernandez, M. Greenway use and preferences in diverse urban communities: Implications for trail design and management. Landsc. Urban Plan. 2018, 172, 47-59. [CrossRef]

14. Zhao, F.; Nie, R.; Zhang, J.E. Greenway Implementation Influence on Agricultural Heritage Sites (AHS): The Case of Liantang Village of Zengcheng District, Guangzhou City, China. Sustainability 2018, 10, 434. [CrossRef]

15. Ulrich, R.S. Aesthetic and affective response to natural environment. In Behavior and the Natural Environment; Springer: Boston, MA, USA, 1983; pp. 85-125.

16. Ittelson, W.H. Environment and Cognition; Seminar Press: Princeton, NJ, USA, 1973.

17. Izard, C.E. Human Emotions; Springer Science \& Business Media: Berlin, Germany, 2013.

18. Zajonc, R.B. Feeling and thinking: Preferences need no inferences. Am. Psychol. 1980, 35, 151. [CrossRef]

19. Lazarus, R.S.; Kanner, A.D.; Folkman, S. Emotions: A cognitive-phenomenological analysis. In Theories of Emotion; Elsevier: Amsterdam, The Netherlands, 1980; pp. 189-217.

20. Lansing, J.B.; Marans, R.W.; Zehner, R.B. Planned Residential Environments; Institute of Survey Research, University of Michigan: Ann Arbor, MI, USA, 1970.

21. Carp, F.M.; Zawadski, R.T.; Shokrkon, H. Dimensions of urban environmental quality. Environ. Behav. 1976, 8, 239-264. [CrossRef]

22. Nasar, J.L. New developments in aesthetics for urban design. In Toward the Integration of Theory, Methods, Research, and Utilization; Springer: Berlin, Germany, 1997; pp. 149-193.

23. Akpinar, A. Factors influencing the use of urban greenways: A case study of Aydın, Turkey. Urban For. Urban Green. 2016, 16, 123-131. [CrossRef]

24. Chon, J.; Shafer, C.S. Aesthetic responses to urban greenway trail environments. Landsc. Res. 2009, 34, 83-104. [CrossRef]

25. Gobster, P.H. Perception and use of a metropolitan greenway system for recreation. Landsc. Urban Plan. 1995, 33, 401-413. [CrossRef]

26. Allton, D.J.; Lieber, S.R. Attributes of Chicago trail areas. Leis. Sci. 1983, 5, 197-220. [CrossRef]

27. Schroeder, H.W.; Anderson, L.M. Perception of personal safety in urban recreation sites. J. Leis. Res. 1984, 16, 178-194. [CrossRef]

28. Ahern, J. Greenways as ecological networks in rural areas. In Landscape Planning and Ecological Networks, 6th ed.; Elsevier Science: Amsterdam, The Netherlands, 1994; pp. 159-177.

29. Burel, F.; Baudry, J. Social, aesthetic and ecological aspects of hedgerows in rural landscapes as a framework for greenways. Landsc. Urban Plan. 1995, 33, 327-340. [CrossRef]

30. Dawson, K.J. A comprehensive conservation strategy for Georgia's greenways. Landsc. Urban Plan. 1995, 33, 27-43. [CrossRef]

31. Tzolova, G.V. An experiment in greenway analysis and assessment: The Danube River. Landsc. Urban Plan. 1995, 33, 283-294. [CrossRef]

32. Staats, H.; Van Gemerden, E.; Hartig, T. Preference for restorative situations: Interactive effects of attentional state, activity-in-environment, and social context. Leis. Sci. 2010, 32, 401-417. [CrossRef]

33. Kardan, O.; Demiralp, E.; Hout, M.C.; Hunter, M.R.; Karimi, H.; Hanayik, T.; Yourganov, G.; Jonides, J.; Berman, M.G. Is the preference of natural versus man-made scenes driven by bottom-up processing of the visual features of nature? Front. Psychol. 2015, 6, 471. [CrossRef] [PubMed] 
34. Gobster, P.H. Urban bicycle trails: Use patterns and user preferences. Trends 1988, 25, 21-25.

35. Gobster, P.H. The Illinois Statewide Trail User Study; USDA Forest Service, North Central Forest Experiment Station: Chicago, IL, USA, 1990.

36. Flink, C.; Olka, K.; Searns, R. Trails for the Twenty-First Century: Planning, Design, and Management Manual for Multi-Use Trails; Island Press: Washington, DC, USA, 2001.

37. Gobster, P.H. Recreation and leisure research from an active living perspective: Taking a second look at urban trail use data. Leis. Sci. 2005, 27,367-383. [CrossRef]

38. Nasar, J.L. The evaluative image of the city. J. Am. Plann. Assoc. 1990, 56, 41-53. [CrossRef]

39. Driver, B.L. Managing to Optimize the Beneficial Outcomes of Recreation; Venture Publishing: Pennsylvania, USA, 2008.

40. Taylor, P. What factors make rail trails successful as tourism attractions? Developing a conceptual framework from relevant literature. J. Outdoor Recreat. Tour. 2015, 12, 89-98. [CrossRef]

41. Balestrieri, M.; Congiu, T. Rediscovering Rural Territories by Means of Religious Route Planning. Sustainability 2017, 9, 363. [CrossRef]

42. Nasar, J.L. Perception and evaluation of residential street scenes. In Directions in Person-Environment Research and Practice; Routledge in Association with GSE Research: London, UK, 1999; Volume 229, pp. $229-247$.

43. Loures, L.; Loures, A.; Nunes, J.; Panagopoulos, T. Landscape valuation of environmental amenities throughout the application of direct and indirect methods. Sustainability 2015, 7, 794-810. [CrossRef]

44. Daniel, T.C.; Vining, J. Methodological issues in the assessment of landscape quality. In Behavior and the Natural Environment; Springer: Berlin, Germany, 1983; pp. 39-84.

45. Hartig, T.; Evans, G.W. Psychological foundations of nature experience. In Advances in Psychology; Elsevier: Amsterdam, The Netherlands, 1993; Volume 96, pp. 427-457.

46. Herzog, T.R. A cognitive analysis of preference for waterscapes. J. Environ. Psychol. 1985, 5, $225-241$. [CrossRef]

47. Kaplan, S. The restorative benefits of nature: Toward an integrative framework. J. Environ. Psychol. 1995, 15, 169-182. [CrossRef]

48. Asakawa, S.; Yoshida, K.; Yabe, K. Perceptions of urban stream corridors within the greenway system of Sapporo, Japan. Landsc. Urban Plan. 2004, 68, 167-182. [CrossRef]

49. Reynolds, K.D.; Wolch, J.; Byrne, J.; Chou, C.-P.; Feng, G.; Weaver, S.; Jerrett, M. Trail characteristics as correlates of urban trail use. Am. J. Health Promot. 2007, 21, 335-345. [CrossRef] [PubMed]

50. Arendt, R. Linked landscapes: Creating greenway corridors through conservation subdivision design strategies in the northeastern and central United States. Landsc. Urban Plan. 2004, 68, 241-269. [CrossRef]

51. Flink, C.A.; Searns, R.M. Greenways: A Guide to Planning, Desing, and Development; Island Press: Washington, DC, USA, 1993.

52. Tan, K.W. A greenway network for Singapore. Landsc. Urban Plan. 2006, 76, 45-66. [CrossRef]

53. Yahner, T.G.; Korostoff, N.; Johnson, T.P.; Battaglia, A.M.; Jones, D.R. Cultural landscapes and landscape ecology in contemporary greenway planning, design and management: A case study. Landsc. Urban Plan. 1995, 33, 295-316. [CrossRef]

54. Mahdjoubi, L.; Wiltshire, J. Towards a framework for evaluation of computer visual simulations in environmental design. Des. Stud. 2001, 22, 193-209. [CrossRef]

55. Al-Kodmany, K. Visualization tools and methods for participatory planning and design. J. Urban Technol. 2001, 8, 1-37. [CrossRef]

56. Craik, K.H.; McKechnie, G.E. Personality and the Environment; Sage Publications Inc.: Thousand Oaks, CA, USA, 1978; Volume 42.

57. Herzog, T.R.; Flynn-Smith, J.A. Preference and perceived danger as a function of the perceived curvature, length, and width of urban alleys. Environ. Behav. 2001, 33, 653-666. [CrossRef]

58. Wohlwill, J.F. Environmental aesthetics: The environment as a source of affect. In Human Behavior and Environment; Springer: Berlin, Germany, 1976; pp. 37-86.

59. Henshel, R.L. The purposes of laboratory experimentation and the virtues of deliberate artificiality. J. Exp. Soc. Psychol. 1980, 16, 466-478. [CrossRef]

60. Martin, M.W.; Sell, J. The role of the experiment in the social sciences. Sociol. Q. 1979, 20, 581-590. [CrossRef]

61. Hellmund, P.C.; Smith, D. Designing Greenways: Sustainable Landscapes for Nature and People; Island Press: Washington, DC, USA, 2013. 
62. Nassauer, J.I. Messy ecosystems, orderly frames. Landsc. J. 1995, 14, 161-170. [CrossRef]

63. Howard, D. Geographic Information Technologies and Community Planning: Spatial Empowerment and Public Participation. In Proceedings of the Project Varenius Specialist Meeting: Empowerment, Marginalization, and Public Participation GIS, Santa Barbara, CA, USA, 15-17 October 1998; Available online: http://www.ncgia.ucsb.edu/varenius/ppgis/papers/howard.html (accessed on 29 January 2006).

64. Sanoff, H. Facility programming. In Advance in Environment, Behavior, and Design; Springer: Berlin, Germany, 1989; pp. 239-286.

(C) 2019 by the authors. Licensee MDPI, Basel, Switzerland. This article is an open access article distributed under the terms and conditions of the Creative Commons Attribution (CC BY) license (http://creativecommons.org/licenses/by/4.0/). 